\title{
Use of a commercial ELISA kit specific for glycoprotein E peptides to indirectly detect Caprine Herpesvirus 1 (CpHV-1) in the state of São Paulo, Brazil
}

\author{
Uso de kit ELISA comercial específico para peptídeos da \\ glicoproteína E para detecção indireta de Herpesvírus \\ Caprino tipo 1 ( $\mathrm{CpHv}$-1) no estado de São Paulo, Brasil
}

\author{
Lilian Gregory' (1) (orcid.org/0000-0003-0240-3025) \\ Natália Carrillo Gaeta1* (D) (orcid.org/0000-0001-6397-605X) \\ Astrid Bettini2 (D) (orcid.org/0000-0001-8475-5694) \\ Marco Ceol ${ }^{2}$ (D) (orcid.org/0000-0002-0312-3618) \\ Alexander Tavella² (D) (orcid.org/0000-0001-8565-9987)
}

\begin{abstract}
Caprine herpesvirus $1(\mathrm{CpHV}-1)$ infection is associated with clinical manifestations related to animal age, with high mortality in kids and infertility in adults. Given the scarcity of research about the epidemiological situation of this infection in Brazilian flocks, we aimed to conduct a cross-sectional descriptive study to detect antibodies against CpHV-1 in goats in the state of São Paulo, Brazil. Fifty-five male and female goats — kids and adult - were assessed in this study. Blood serum was analyzed by a commercial ELISA kit to detect antibodies against CpHV-1, which had not been used in Brazil before. No animals were reactive. Brazil lacks information about $\mathrm{CpHV}-1$ infection in goat flocks. Continuing the study is crucial to understand the epidemiological situation of the disease and establish protocols for infection control.
\end{abstract}

KEYWORDS: recombinant antigen; serum diagnosis; immunoenzymatic assay; small ruminants.
RESUMO: A infecção pelo Herpesvírus Caprino tipo 1 (CpHv-1) está associada a manifestaçóes clínicas relacionadas à idade dos animais, com alta mortalidade em filhotes e infertilidade em adultos. Diante da escassez de estudos sobre situação epidemiológica dessa infecçáo nos rebanhos brasileiros, a presente pesquisa teve como objetivo realizar um estudo transversal e descritivo para a detecção de anticorpos anti-Herpesvírus Caprino tipo $1 \mathrm{em}$ caprinos do estado de São Paulo, Brasil. Foram avaliados 55 caprinos machos e fêmeas, filhotes e adultos. O soro sanguíneo foi analisado por um kit ELISA comercial para detecção de anticorpos contra $\mathrm{CpHv}-1$, de utilização inédita no Brasil. Nenhum animal estudado foi sororreagente. $\mathrm{O}$ Brasil carece de informaçóes acerca da infecção pelo Herpesvírus Caprino tipo 1 nos rebanhos caprinos do país. A continuidade do estudo é imprescindível para compreender a situação epidemiológica da enfermidade e estabelecer protocolos para controle da infecção.

PALAVRAS-CHAVE: antígeno recombinante; sorodiagnóstico; ensaio imunoenzimático; pequenos ruminantes.

'Department of Internal Medicine, School of Veterinary Medicine and Animal Science, Universidade de São Paulo - São Paulo (SP), Brazil

${ }^{2}$ Laboratory for Serology and Technical Assistance, Istituto Zooprofilattico Sperimentale delle Venezie - Bolzano, Italy

*Corresponding author: natalia.gaeta@hotmail.com

Received on: 01/21/2020; Accepted on: 06/18/2020 
Caprine herpesvirus 1 (CpHV-1) belongs to the family Herpesviridae, subfamily Alphaherpesvirinae, genus Varicellovirus, which includes other important genetically related viruses, such as bovine herpesvirus 1 and 5 and human herpesvirus 3 (ICTV, 2019). CpHV-1 was first isolated from goat kids with severe enteritis in the United States (SAITO et al., 1974). Herpesviridae family members are recognized for establishing a latent infection, remaining in nervous ganglia, and propagating through the body after stressful situations, such as weaning, transport, estrus, and childbirth. Hence, the immune function decreases, and the infection is reactivated (TEMPESTA et al., 1998).

Clinical signs of $\mathrm{CpHV}-1$ infection are related to age. Inapparent infection is usually observed in adults, although a few animals can show respiratory disorders, vulvovaginitis, balanoposthitis, infertility, and abortion in the second half of pregnancy (TARIGAN et al., 1987; TEMPESTA et al., 1999; PIPER et al., 2008). Fever, dyspnea, conjunctivitis, and ulcerative and necrotic gut lesions are detected in 2-week-old goats. High morbidity and mortality rates are common at this age (METTLER et al., 1979). Infection mainly occurs by contact with respiratory and genital discharge from infected animals (TEMPESTA et al., 2002).

CpHV-1 infection has been detected in several countries, such as the United States (WILLIAMS et al., 1997), Mexico (LLANOS-SALINAS et al., 2018), Italy (BERTOLINI et al., 2018), Spain (KEUSER et al., 2004), France (SUAVET et al., 2016), Canada (CHÉNIER et al., 2004), and New Zealand (HORNER et al., 1982). Serological surveys of CpHV-1 have been carried out in a few Brazilian states, such as Paraíba (SILVA et al., 2013) and São Paulo (NOGUEIRA et al., 2010), where 89.1 and $16 \%$ of seroreactive animals were detected, respectively, by virus-neutralization test (VNT).

The disease is important for small ruminant production, and given the scarcity of studies aimed at better understanding the epidemiological situation of this infection in Brazilian flocks, we sought to conduct a cross-sectional descriptive study of indirect detection of CpHV-1 in goats in the state of São Paulo, Brazil, using a commercial ELISA kit specific for $\mathrm{CpHV}-1$ glycoprotein E peptides, which had not been used in the country before.

The present research is a collaboration between the Department of Internal Medicine of the School of Veterinary Medicine and Animal Science, Universidade de São Paulo, Brazil, and the Institute for Animal Health Control (Istituto Zooprofilattico Sperimentale delle Venezie - IZSV) in Bolzano, Italy.

This cross-sectional descriptive study was conducted with 55 male and female goats. The 34 adults and 21 kids (four to seven months old) belonged to two different herds ( $\mathrm{A}=18$; $B=37)$ from the state of Sáo Paulo, Brazil. No animal showed reproductive disorder or respiratory disease clinical signs. All animal procedures had been previously approved by the Ethics
Committee of the School of Veterinary Medicine and Animal Science, Universidade de Sáo Paulo (Protocol no. 2585/2011).

Blood samples were collected from each animal by jugular venipuncture using a vacuum tube system without anticoagulants (Vacutainer ${ }^{\oplus}, \mathrm{BD}$, Juiz de Fora, Brazil). Serum was obtained by blood centrifugation at $2600 \times \mathrm{g}$ for $15 \mathrm{~min}-$ utes, and samples were transferred to microtubes and stored at $-20^{\circ} \mathrm{C}$ until analysis. All serum samples were shipped to IZSV, where serum diagnosis was performed using a commercial ELISA kit (Eradikit ${ }^{\circledR} \mathrm{CpHV}$-1 Indirect ELISA screening test, IN3 Diagnostics, Torino, Italy), which had not been used in Brazilian samples before. This ELISA kit uses plates coated with peptides (CpHV-1 glycoprotein E). All procedures followed the manufacturer's instructions.

Fifty-five serum samples from male and female goats adults and kids - were evaluated using a commercial ELISA kit. No reactive animals were detected in this study.

Goats infected with CpHV-1 may show different clinical signs according to age. The infection is similar to that of bovine herpesvirus 1: $\mathrm{CpHV}-1$ can cause reproductive disorders in adults and gastrointestinal ulcerations in kids (PIPER et al., 2008). In the present research, no animal showed clinical signs of $\mathrm{CpHV}-1$ infection during sample collection, and no reactivity was detected.

Our results are in agreement with those of recent Brazilian research that did not detect reactive goats in the states of São Paulo and Minas Gerais (BORGES, 2015). Antibodies against $\mathrm{CpHV}-1$ were detected in $16 \%$ of animals in the city of Sorocaba, state of São Paulo, using VNT (NOGUEIRA et al., 2010), which indicates the presence of CpHV-1 in this state. BROWN et al. (1989) identified $34.6 \%$ of reactive samples in five out of nine states of the Brazilian northeast region. Eighty-nine percent of flocks and $36.6 \%$ of goats from the state of Paraíba showed antibodies against CpHV-1, and natural mounting was the most important risk factor for CpHV-1 infection (SILVA et al., 2013). We highlight that the variability of the results in different surveys may be related to the different tests performed, the health history of the flock, and the presence of infection-free areas. Considering that $\mathrm{CpHV}-1$ infection was identified in the Brazilian northeast and southeast regions, animal transit control between these two regions is important to prevent the spread of the infection to areas that are possibly free of $\mathrm{CpHV}-1$. Accurate diagnostic techniques are essential to control $\mathrm{CpHV}-1$ infection in Brazilian flocks.

In this research, a commercial ELISA kit based on CpHV-1 glycoprotein E peptides was used for the first time in Brazilian samples. VNT is only capable of detecting antibodies related to neutralization and has been used in other CpHV-1 studies. Performing VNT, SILVA et al. (2013) detected crossreactivity between $\mathrm{CpHV}-1$ and bovine herpesvirus 1/bovine herpesvirus 2. On the other hand, ELISA identifies antibodies related to structural and non-structural viral proteins and 
has been considered more specific and sensitive in detecting CpHV-1 when compared to VNT (CORTEZ et al., 2001; BERTOLOTTI et al., 2013). BERTOLOTTI et al. (2013) demonstrated that the sensitivity and specificity of CpHV-1 gE ELISA was 97.11 and $98.57 \%$, respectively, and observed low or non-cross-reactivity with bovine herpesvirus 1 glycoprotein $\mathrm{E}$.
Thus, serological surveys of $\mathrm{CpHV}-1$ infection would be more reliable when compared to studies conducted using VNT.

Brazil lacks information about $\mathrm{CpHV}-1$ infection in goat flocks, and further studies are necessary to understand its epidemiological situation better and establish protocols for infection control.

ACKNOWLEDGMENTS: Not applicable.

FUNDING: NCG is supported by Fundação de Amparo à Pesquisa do Estado de São Paulo (grant number 2016/23204-9). This study was financed in part by the Coordenação de Aperfeiçoamento de Pessoal de Nível Superior - Brasil (CAPES) Finance Code 001.

CONFLICTS OF INTEREST: All authors declare that they have no conflict of interest.

ETHICAL APPROVAL: This study was approved by the Ethics Committee of the School of Veterinary Medicine and Animal Science, Universidade de São Paulo, under protocol number 2585/2011.

AVAILABILITY OF DATA AND MATERIAL: Data sharing not applicable to this article as no datasets were generated or analyzed during the current study.

AUTHORS' CONTRIBUTIONS: Conceptualization: Gregory, L.; Formal analysis: Bettini, A.; Ceol, M.; Tavella, A.; Methodology: Bettini, A.; Ceol, M.; Tavella, A.; Writing - original draft: Gaeta, N.C.; Writing - review \& editing: Gaeta, N.C.; Gregory, L.

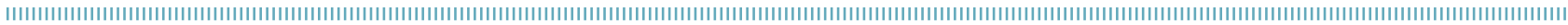

\section{REFERENCES}

BERTOLOTTI, L.; ROSAMILIA, A.; PROFITI,, M.; BROCCHI, M.; MASOERO, L.; FRANCESCHI, V.; TEMPESTA, M.; DONOFRIO, G.; ROSATI, S. Characterization of caprine herpesvirus 1 (CpHV 1) glycoprotein $\mathrm{E}$ and glycoprotein I ectodomains expressed in mammalian cells. Veterinary Microbiology, v.164, n.3-4, p.222-228, 2013. https://doi.org/10.1016/j.vetmic.2013.02.008

BERTOLINI, S.; ROSAMILIA, A.; CARUSO, C.; MAURELLA, C.; INGRAVALLE, F.; QUASSO, A.; ACUTIS, P.L.; PITTI, M.; MASOERO, L.; RU, G. A cross-sectional study to identify a set of risk factors for caprine herpesvirus 1 infection. BMC Veterinary Research, v.14, n.1, p.94, 2018. https://doi.org/10.1186/ s12917-018-1401-8

BORGES, L. Monitoração dos parâmetros reprodutivos e perfil sorológico do herpesvírus caprino tipo 1 e do herpesvírus bovino tipo 1 em rebanhos caprinos dos estados de São Paulo e Minas Gerais. 2015. 66f. Thesis (Doctor of Veterinary Medicine) - Universidade Estadual Paulista Júlio de Mesquita Filho, Faculdade de Ciências Agrárias e Veterinárias de Jaboticabal, Jaboticabal, 2015.

BROWN, C.C.; OLANDER, H.J.; CASTRO, A.E.; BEHYMER, D.E. Prevalence of antibodies in goats in north-eastern Brazil to selected viral and bacterial agents. Tropical Animal Health and Production, v.21, n.3, p.167-169, 1989. https://doi. org/10.1007/bfO2250827
CHÉNIER, S.; MONTPETIT, C.; HÉLIE, P. Caprine herpesvirus-1 abortion storm in a goat herd in Quebec. The Canadian Veterinary Journal, v.45, n.3, p.241-243, 2004.

CORTEZ, A.; HEINEMANN, M.B.; ALFIERI, A.A.; MÉDICI, K.C.; ALFIERI, A.F.; OLIVEIRA, D.B.; MEYER, A.D.; SOARES, R.M.; SAKAMOTO, S.M.; AMARAL, R.; BARUSELLI, P.S.; FUJI, T.; RUCHTZENHAIN, L.J. Comparação das técnicas de ELISA indireto e de soroneutralização na detecção de anticorpos contra o BHV-1 em amostras de soro bubalino (Bubalus bubalis). Brazilian Journal of Veterinary Research and Animal Science, v.38, n.3, p.146-148, 2001. https://doi. org/10.1590/S1413-95962001000300010

HORNER, G.W.; HUNTER, R.; DAY, A. An outbreak of vulvovaginitis in goats caused by a caprine herpesvirus. New Zealand Veterinary Journal, v.30, n.10, p.150-152, 1982. https://doi. org/10.1080/00480169.1982.34919

INTERNATIONALCOMMITEEONTAXONOMYOFVIRUSES(ICTV). 2019. Available from: https://talk.ictvonline.org/taxonomy/p/taxonomyhistory?taxnode_id=201901444. Access on: Jan. 202020.

KEUSER, V.; ESPEJO-SERRANO, J.; SCHYNTS, F.; GEORGIN, J.P.; THIRY, E. Isolation of caprine herpesvirus type 1 in Spain. Veterinary Record, v.154, n. 13, p.395-399, 2004. http://dx.doi. org/10.1136/vr.154.13.395 
LLANOS-SALINAS, S.P.; COBOS-MARÍN, L; CANDANOSA-ARANDA, E. Immunohistochemical diagnosis of Caprine alphaherpesvirus 1 (CpHV-1) in Mexico. Austral Journal of Veterinary Sciences, v.50, n.3, p. 139-142, 2018. http://dx.doi.org/10.4067/SO719-81322018000300139

METTLER, F.; ENGELS, M.; WILD, P.; BIVETTI, A. Herpesvirus infection in kids in Switzerland. Schweizer Archiv fur Tierheilkunde, v.121, n.12, p.655-662, 1979.

NOGUEIRA, A.H.C.; OKUDA, L.H.; STEFANO, E.; CHIEBAO, D.P.; RIBEIRO, C.; LARA, M.C.C.S.H.; VILLALOBOS, E.M.C.; CARDOSO, M.V.; PITUCO, E.M. Detection of caprine herpesvirus (CpHV-1) in small ruminants in the Sorocaba region, São Paulo, Brazil. In: ENCONTRO NACIONAL DE VIROLOGIA, 21., 2010, Gramado. Virus Reviews \& Research, 2010. v.15. p.151-152.

PIPER, K.; FITZGERALD, C.J.; FICORILLI, N.; STUDDERT, M.J. Isolation of caprine herpesvirus 1 from a major outbreak of infectious pustular vulvovaginitis in goats. Australian Veterinary Journal, v.86, n.4, p.136-138, 2008. https://doi. org/10.1111/j.1751-0813.2008.00273.x

SAITO, J.K.; GRIBBLE, D.H.; BERRIOS, P.E.; KNIGHT, H.D.; MCKERCHER, G.D. A new herpesvirus isolates from goats: preliminary report. American Journal of Veterinary Research, v.35, p.847-848, 1974.

SILVA, M.L.C.R.; PITUCO, E.M.; NOGUEIRA, A.H.C.; MARTINS, M.S.N.; LIMA, M.S.; AZEVEDO, S. Serological evidence and risk factors associated with Caprine herpesvirus 1 in dairy goat flocks in a semiarid region of northeastern Brazil. Journal of Veterinary Diagnostic Investigation, v.25, n.1, p.125-128, 2013. https:// doi.org/10.1177/1040638712470946
SUAVET, F.; CHAMPION, J.L.; BARTOLINI, L.; MERNOU, M.; ALZIEU, J.P.; BRUGIDOU, R.; DARNATIGUES, S.; REYNAUD, G.; PERRIN, C.; ADMAM, G.; THIERY, R.; DUQUESNE, V. First description of infection of Caprine Herpesvirus 1 (CpHV-1) in goats in Mainland France. Pathogens, v.5, n.1, p.17, 2016. https://doi.org/10.3390/ pathogens 5010017

TARIGAN, S.; WEBB, R.F.; KIRKLAND, D. Caprine herpesvirus from balanoposthitis. Australian Veterinary Journal, v.64, n.10, p.321-321, 1987.https://doi.org/10.1111/j.1751-0813.1987. tb07345.x

TEMPESTA, M.; BUONAVOGLIA, D.; SAGAZIO, P.; PRATELLI, A.; BUONAVOGLIA, C. Natural reactivation of caprine herpesvirus 1 in latently infected goats. Veterinary Record, v.143, n.7, p.200, 1998. http://dx.doi.org/10.1136/vr.143.7.200

TEMPESTA, M.; PRATELLI, A.; CORRENTE, M.; BUONAVOGLIA, C. A preliminary study on the pathogenicity of a strain of caprine herpesvirus-1. Comparative Immunology, Microbiology and Infectious Diseases, v.22, n.2, p.137-143, 1999. https://doi. org/10.1016/SO147-9571(98)00029-0

TEMPESTA, M.; GRECO, G.; CAMEROAMERO, M.; BOZZO, G.; GUARDA, F.; BUONAVOGLIA, C. Virological and histological findings in goats infected by caprine herpesvirus 1 . The New Microbiologica, v.25, n.3, p.281-284, 2002.

WILLIAMS, N.M.; VICKERS, M.L.; TRAMONTIN, R.R.; PETRITESMURPHY, M.B.; ALLEN, G.P. Multiple abortions associated with caprine herpesvirus infection in a goat herd. Journal of the American Veterinary Medical Association, v.21 1, n. 1, p.89-91, 1997. 